\section{Kastamonu Eğitim Dergisi Kastamonu Education Journal}

Kasım 2019 Cilt:27 Sayı:6

kefdergi.kastamonu.edu.tr
Başvuru Tarihi/Received: 15.05.2019

Kabul Tarihi/Accepted: 09.08.2019

DOI: $10.24106 /$ kefdergi.3797

\title{
Farklı Ülke Vatandaşı Öğrencilerin İletişim Kurma ve Çatışmaları Çözme Anlayışlarının İncelenmesi
}

\section{The Examination on Communication and Dissenting Disputes in Different Nationalities' Students}

\section{Öz}

\author{
Zekerya BATUR ${ }^{1}$, Murat BAŞAR², Nurcan ŞENER ${ }^{3}$, Kamil UYGUN ${ }^{4}$
}

İletişim, insanların sosyalleşmesini sağlayan en önemli unsurların başında gelmektedir. Bu iletişim unsurları aracılığıyla insanlar arasında bir etkileşim başlamaktadır. İnsanlar etkileşimi iletişime evirmek için bazen kelimelere bazen de beden diline başvurmaktadırlar. Bu bağlamda günlük yaşamda insanlar bu unsurları yerinde ve zamanında kullandığında daha başarılı bir iletişim gerçekleştirebilmektedir. Dolayısıyla insanların iletişim becerilerini arttırmak için hem sözel hem de beden dilini eşgüdümlü kullanmaları gerekmektedir. Özellikle beden dilinin kullanımı etkili iletişim için ayrı bir yere sahiptir. Çünkü beden dilinin kullanımında kültürel özellikler devreye girmektedir. Kültürel özelliklerin devreye girmesiyle birlikte etkili iletişimin boyutu da değişebilmektedir. Bu çalışmanın amacı farklı ülke vatandaşı olan öğrencilerin iletişim kurma ve çatı̧̧maları çözme anlayışlarını incelemektir. Çalışma nitel araştırma yöntemine göre desenlenmiş olup çalışmada toplanan verilerin incelenmesinde betimsel analiz kullanılmıştır. Çalışma grubu Türkiye'de lisans programlarında eğitimine devam eden Türkiye 5, Azerbaycan 4, Türkmenistan 5, Mali 5, Somali 5, Fransa 4 ve Gine'den 5 olmak üzere toplam 33 öğrenciden oluşmaktadır. Çalışmanın verileri yapılandırımış görüşme tekniğiyle toplanmıştır. Öğrencilerle bire bir farklı saatlerde görüşülmüş, sorulara verdikleri cevaplar not edilmiştir. Daha sonra her soruya verilen cevaplar tablolaştrılarak ülkelere göre öğrenciler kodlanmıştır. Toplanan veriler içerik analizine tabi tutulmuştur. Çalışmanın sonucunda öğrencilerin iletişim kurma ve çatş̧ma çözme anlayışlarının bazı noktalarda benzer, bazı noktalarda ise farklılaştığı görülmüştür. Sonuçlara göre, etkili iletişimde ilk iletişime geçilenler arasında aile ve arkadaş yer almaktadır. Etkili iletişimde çatş̧mayı çözücü olarak ise sırasıyla aile, arkadaş ve uzmana başvurulduğu görülmüştür.

\section{Anahtar Kelimeler: iletişim, etkili iletişim, çatışma çözme}

\section{Abstract}

People sometimes use words and sometimes body language to invert interaction to communication. Especially, the use of body language has an important place for effective communication since cultural features come in to play in the use of body language. With the introduction of cultural features, the dimension of effective communication can change. The aim of this study is to examine the understanding of communicating and resolving conflicts among students of different nationalities. The study was qualitative and content analysis was used in studying collected data. The study group consist of 5 students from Turkey, 4 students from Azerbaijan, 5students from Turkmenistan, 5 students from Mali, 5 students from Somalia, 4 students from France, 5 students from Guinea, total of 33 students who continue their education in undergraduate programs in Turkey. The data of the study was collected by structured interview technique. The students were interviewed at different times, and the answers that they gave to the questions were noted. Then the answers given to each question were tabulated and the students were coded according to the countries. The collected data were subjected to content analysis. In the result of the study, students' understanding of communication and conflict resolution seemed to be similar at some points and at some points differentiated. According to the results, the first communication in effective communication is family and friends. It was seen that family, friends and experts are consulted respectively in order to solve the conflict in effective communication.

Keywords: communication, effective communication, conflict to solve

1. Uşak Üniversitesi, Eğitim Fakültesi, Türkçe ve Sosyal Bilimler Eğitimi, Uşak, Türkiye; https://orcid.org/0000-0002-7918-5305

2. Uşak Üniversitesi, Eğitim Fakültesi, Temel Eğitim Bölümü, Uşak, Türkiye; https://orcid.org0000-0001-6635-4563/

3. Marmara Üniversitesi, Atatürk Eğitim Fakültesi, Temel Eğitim Bölümü, İstanbul, Türkiye; https://orcid.org0000-0002-1987-1717/

4. Uşak Üniversitesi, Eğitim Fakültesi, Türkçe ve Sosyal Bilimler Eğitimi, Uşak, Türkiye; https://orcid.org/0000-0002-8971-328X

Attf / Citation: Batur, Z., Başar, M., Şener, N. \& Uygun, K. (2019). The examination on communication and dissenting disputes in different nationalities' students. Kastamonu Education Journal, 27(6), 2781-2794. doi:10.24106/kefdergi.3797 


\section{Extended Abstract}

\section{Introduction}

Communication is one of the most important elements that enable people to socialize. Interaction between people starts via these communication elements. People sometimes use words and sometimes body language to invert interaction to communication. Especially, the use of body language has an important place for effective communication since cultural features come in to play in the use of body language. With the introduction of cultural features, the dimension of effective communication can change. This study aims to reveal how students communicate, with whom they communicate and whom they seek solutions with for their communication problems. Do the foreign students' approaches of communicating and the way they dissent the disputes differentiate?

\section{Research Model}

The present research employed a case study, as a qualitative research method. Since the process which is aimed to be studied upon happens naturally and the researchers intend to investigate the situation in detail, they tend to perform a case study.

\section{The Study Group}

The study group is determined as 33 voluntary students from 7 different countries enrolled at Uşak University during the 2017-2018 Academic Year. The distribution of students is as follows: in terms of easy accessibility, 5 Turkish, 4 Azerbaijani, 5 Turkmenistan, 5 Malian, 5 Somalian, 4 French and 5 Guinean students comprise the study group.

\section{Data Collection Tool}

Related literature has been searched as a data collection tool with the purpose of investigating the students' opinions upon approaches of communicating and dissenting disputes. The questions of communication and dissenting disputes have been formed. In addition, based on expert opinions, interview forms have been used. The interview forms have been formed by 3 Turkish and 2 Physiological Counselling and Guidance experts. In the end, the attendants of the study have been given the questions in the data collection tools and the results have been obtained.

Data Analysis

In the present study, the quotations have been given directly in accordance with the descriptive analysis pattern. The conclusive data have been coded, statements of the attendants have been categorized according to the questions and they have been gathered under related questions. The attendants' statements have been taken directly. During reporting process, codes have been used for the attendants. Turk1 for Turkish students, A1 for Azerbaijani students, T1 for Turkmen students, M1 for Malian students, S1 for Somalian students, F1 for French students and G1 for Guinean students have been utilized. The data gathered from the study have been offered to experts and the points they have agreed on have been included in the findings of the study.

\section{Findings}

The fact that students focus on speaker's body language is worth notice. On the contrary, students have not mentioned about the content or style of the speech. For this reason, it may be concluded that the words uttered during communication do not directly mean a lot for them.

\section{Discussion and Results}

Tone of voice is an important feature for the other ones except from Turkish students. In daily life, voice is considered to be important in that it both facilitates communication and has an impression on people. In addition, another factor which affects communication is style of dressing since clothes are regarded as important elements in most cultures. Style of dressing, as is known, has become a sign of the status and social prestige for people in many fields of business. In social life, people's style of hair and dressing represents their communicating skills. In conclusion, communication and dissenting the disputes require a skill. It is essential to gain this skill in the family, improve and maintain it in formal environments. 


\section{Introduction}

Communication is defined as the act of transferring information from one person to another. However, there may be several factors affecting this process. These factors are specified as sender, receiver, communication channel, feedback, ideas and noise (Renn and Levine, 1991; Rains and Scott, 2007; Liyanage et al., 2009; Deniz, 2013). In addition, such factors as person's psychological state, his/her environment and knowledge also alter the level of communication. With this regard, there are several reasons which promote or weaken communication. Using the means of communication correctly, thus, enables communication to be more effective. An effective communication is accompanied by an effective speaking, thereby promoting an effective communication. An efficient communication affects every aspect of life from inside out or vice versa. It has been proved in the previous studies that an effective communication skill has a key role among family members, work or friend relationships (Michael, Harvey and Griffith, 2002; Leonard, Graham and Bonacum, 2004; Halawah, 2005; Suter et al., 2009; Bozorgian, 2012; Hamouda; 2013). According to other studies, even the way mother communicates her child or husband affects the child's development differently (Stewart, 1978; M. Cochran and Brassard, 1979; Ainsworth, 1979; Hoff, 2003). Therefore, an effective and better communication in social life is very important. Family environment is the first place where socializing and language acquisition start. It is very unlikely for a child to maintain a healthy communication unless $\mathrm{s} /$ he experiences good communication examples in his/ her family. In addition, those children have been found to have similar difficulties to their parents while communicating other people. However, there are several factors which trigger disputes during communication process. Among these factors are the technological devices- the inevitable elements of our lives (Kraut et al., 1990; Selwyn, 2003; Aksüt, Batur and Avşar, 2006; Aksüt and Batur, 2007; Pierce, 2009). The more common the use of such devices becomes, the more the number of disputes during communication process increases. It has been determined that people in the same environment prefer communicating with one another via mobiles or laptops (Batur, 2010; Batur and Uygun, 2012). This leads both health problems and difficulties in communication skills. Therefore, the use of technological devices gradually debilitates speaking skill which is key element of communication. As a result of lack of speaking, listening problems among people emerges. Based on the previous studies, it has been considered that the main reason of the communication disputes is this situation (Sypher, 1989; Vandergrift, 1997; Goh, 2000; Graham, 2006; Moore et al., 2009; Lotfi, 2012). It has also been revealed that those communication disputes harm the institution of marriage which is the main element of society. In the studies related to communication disputes, depending on the lack of listening, the problem that partners do not understand one another underlies the communication disputess. This problem leads to communication disputes (Street, Brady and Putman, 1983; Castleberry and Shepherd, 1993; Brownell, 1994; Ryan et al., 1995; Janusik and Wolvin, 2002; Socha and Pitts, 2009; Mwolvin, 2010; Ames et al., 2012; Lau, 2017; Başar, Doğan, Şener, Uzun ve Topal, 2018). In conclusion, it has been found out that the important part of communication is listening and understanding the other party. In order for people to understand what is being listened, a great effort is a must. During a listening process, a careful listening requires taking notes and asking incomprehensible points again. Listening to others correctly and carefully is regarded as being related to dignifying someone. Correct listening, during a communication process, facilitates and expedites the process of finding solutions for communication disputes. This study aims to reveal how students communicate, with whom they communicate and whom they seek solutions with for their communication problems.

\section{Problem Statement}

Do the foreign students' approaches of communicating and the way they dissent the disputes differentiate?

\section{Sub-Statements}

- What do foreign students think about effective communication?

- According to their opinions, which factors have an effect upon effective communication?

- How should the beginning of the communication be according to the students?

- What do the students think about the way the communication is ended?

- Who do the students communicate first in their daily life?

- Who do the students consult first for a solution when they experience a communication conflict?

- Who solves the conflict more easily when the students have a communication conflict in their daily life?

- What do the students think about developing empathy during communication?

- What do the students think about developing sympathy during communication?

- Which features of the speaker draw attention during communication process according to the students 


\section{Method}

\section{Research Model}

The present research employed a case study, as a qualitative research method. Since the process which is aimed to be studied upon happens naturally and the researchers intend to investigate the situation in detail, they tend to perform a case study. Case studies are suitable for this study in that they investigate the current phenomena in its own habitat and are used in the conditions in which more than one evidence or data source is available (Miles and Huberman, 1994). It has been found out that the most suitable design for this study is single-case embedded design. There are more than sub-unit of analysis in single-case embedded design (Miles and Huberman, 1994). In this study, the only case, in terms of learning and teaching processes, is communication. 'Physical features' and 'physical and cultural differences' are included in sub-units of analysis. The investigation of embedded form of sub-units of analysis has been considered to explain the research question in detail. For this purpose, conclusions based on the research question have been drawn through the data obtained from sub-units of analysis.

\section{The Study Group}

The study group is determined as 33 voluntary students from 7 different countries enrolled at Uşak University during the 2017-2018 Academic Year. The distribution of students is as follows: in terms of easy accessibility, 5 Turkish, 4 Azerbaijani, 5 Turkmenistan, 5 Malian, 5 Somalian, 4 French and 5 Guinean students comprise the study group.

\section{Data Collection Tool}

Related literature has been searched as a data collection tool with the purpose of investigating the students' opinions upon approaches of communicating and dissenting disputes. The questions of communication and dissenting disputes have been formed. In addition, based on expert opinions, interview forms have been used. The interview forms have been formed by 3 Turkish and 2 Physiological Counselling and Guidance experts. In the end, the attendants of the study have been given the questions in the data collection tools and the results have been obtained.

\section{Data Analysis}

The data have been examined through descriptive analysis. Descriptive analysis aims to offer the edited and interpreted data to the reader (Yıldırım and Şimşek, 2016: 239). In the present study, the quotations have been given directly in accordance with the descriptive analysis pattern. The conclusive data have been coded, statements of the attendants have been categorized according to the questions and they have been gathered under related questions. The attendants' statements have been taken directly. During reporting process, codes have been used for the attendants. Turk1 for Turkish students, A1 for Azerbaijani students, T1 for Turkmen students, M1 for Malian students, S1 for Somalian students, F1 for French students and G1 for Guinean students have been utilized. The data gathered from the study have been offered to experts and the points they have agreed on have been included in the findings of the study.

\section{Findings and Discussion}

This part includes findings and discussion concerning to the data obtained from the students. 
Table 1. Effective Communication Case

\begin{tabular}{|c|c|c|}
\hline Theme & Country & Opinion \\
\hline \multirow{33}{*}{$\begin{array}{l}\text { 1.Effective } \\
\text { Communication }\end{array}$} & Turk 1 & It is a healthy communication between two people. \\
\hline & Turk 2 & It is a proper understanding of the other. \\
\hline & Turk 3 & It is a communication maintained understandably. \\
\hline & Turk 4 & It is the transferring our desires to the others well and correctly. \\
\hline & Turk 5 & It is the understanding and being beneficial for other people. \\
\hline & A 1 & It is the most effective way of speaking. \\
\hline & A 2 & It is the effective speaking. \\
\hline & A 3 & It is the using each word carefully. \\
\hline & A 4 & It is the speaking well. \\
\hline & T 1 & It is the understanding the others. \\
\hline & $\mathrm{T} 2$ & It is the effective speaking and explaining incoherent things. \\
\hline & T 3 & It is the effective speaking. \\
\hline & T 4 & It is being impressive. \\
\hline & T 5 & It is the communicating with the others well. \\
\hline & M 1 & It is the most important skill for life. \\
\hline & M 2 & It improves culture. \\
\hline & M 3 & It is the easy-speaking. \\
\hline & M 4 & It is the process of transferring information. \\
\hline & M 5 & It is the speaking well. \\
\hline & S 1 & It is the most important part of business life. \\
\hline & $S 2$ & It is the mutual agreement. \\
\hline & S 3 & It is the agreement by speaking. \\
\hline & S 4 & It is the process of transferring information. \\
\hline & S 5 & It is the establishment of a dialogue. \\
\hline & F 1 & It is the face-to-face communication in order for the message to be understood well. \\
\hline & $\mathrm{F} 2$ & It is the process of transferring information. \\
\hline & F 3 & It is the effective and friendly discussion. \\
\hline & F 4 & It is the process of communicating well and seriously. \\
\hline & G 1 & It is the establishment of a dialogue. \\
\hline & G 2 & It is a good dialogue. \\
\hline & G 3 & It is the establishment of sincerity. \\
\hline & G 4 & It is the process of communicating seriously. \\
\hline & G 5 & It is the process of communicating. \\
\hline
\end{tabular}

As to the question of 'What do you think is communication?', Turkish students described it as effective communication and transferring the message well and correctly; Azerbaijan students as effective and good speaking; Turkmen students as the process of understanding the others and maintaining good communication; Malian students as an important skill, making a good talking and transferring information; Somalian students as the key point of life and transferring information by effective and good communication; French students as the skill to have face-to-face, informative and friendly communication; Guinean students as dialogue, communication and establishment of a good communication.

The students have identified the communication as both speaking or establishing a dialogue and also as an important means of transferring information and socializing.

Table 2. The Factors Affecting an Effective Communication

\begin{tabular}{|c|c|c|}
\hline Question & Country & Opinion \\
\hline $\begin{array}{l}\text { 2. The factors affecting } \\
\text { effective communication }\end{array}$ & $\begin{array}{l}\text { Turk } 1,2,3,4,5 \\
\text { A } 1 \\
\text { A 2,3,4 } \\
\text { T } 1 \\
\text { T } 2 \\
\text { T } 3 \\
\text { T } 4 \\
\text { T } 5 \\
\text { M } 1,4 \\
\text { M } 2 \\
\text { M } 3 \\
\text { M } 5 \\
\text { S } 1 \\
\text { S } 2 \\
\text { S } 3 \\
\text { S } 4 \\
\text { S } 5 \\
\text { F } 1 \\
\text { F } 2 \\
\text { F } 4 \\
\text { G } 1,2 \\
\text { G } 3 \\
\text { G } 4 \\
\text { G } 5\end{array}$ & $\begin{array}{l}\text { Body language and tone of voice } \\
\text { Wording } \\
\text { Speaking manner } \\
\text { Personality } \\
\text { Wording } \\
\text { Shared knowledge } \\
\text { Tone of voice } \\
\text { Careful listening } \\
\text { Being well-informed } \\
\text { Tone of voice and height } \\
\text { Voice, speaking, gestures } \\
\text { Body language and speaking } \\
\text { Physical Appearance } \\
\text { Behaviour } \\
\text { Mimics } \\
\text { Culture } \\
\text { Being good-humored } \\
\text { Several factors } \\
\text { Being well-informed } \\
\text { Beauty and culture } \\
\text { Loud voice } \\
\text { Being well-informed and cultured } \\
\text { Having a profession and being well-informed } \\
\text { Being well-informed }\end{array}$ \\
\hline
\end{tabular}


As to the question of 'What affects an effective communication?', Turkish students have said that body language, tone of voice and clothing affect an effective communication; Azerbaijani students have said wording and speaking manner; Turkmen students said personality, wording, shared knowledge, tone of voice and careful listening; Malian students said being well-informed, tone of voice and body language; Somalian students said physical appearance, behavior, mimics, being cultured and good-humored; French students said being cultured, beauty and culture and, lastly, Guinean students said loud voice, culture, having a profession and being well- informed affect communication.

The students have regarded physical features of speaking as the factors which influence an effective communication. In addition, it has been revealed that body language and cultural factors also affect communication. First impression is of importance during communication as well. Therefore, the behaviors, from each word to whole body language, influence communication. As a result, it has been concluded that the physical features of speaking have been attached more importance than other factors.

Table 3. Commencement of Communication Case

\begin{tabular}{lcl}
\hline Theme & Country & \\
\hline & Turk 1 & By developing empathy \\
Turk 2 & By eye contact \\
Turk 3 & By smiling \\
Turk 4 & By posing confidence \\
Turk 5 & By listening \\
A 1 & By listening \\
A 2 & By understanding \\
& A 3 & It depends on the person. \\
& A 4 & It depends on the personality. \\
& T 1 & By greeting \\
& T 2 & By greeting and asking questions \\
& T 3,4 & By talking \\
3. The Beginning of & By becoming acquainted with somebody \\
the Communication & M 1,2 & By greeting \\
& M 3 & By greeting and becoming acquainted with somebody \\
M 4,5 & By smiling \\
& S 1,2 & By becoming acquainted with somebody \\
S 3,4 & By talking \\
S 5 & By greeting \\
& F 1 & It depends on the person. \\
& F 2,4 & By smiling \\
F 3 & It starts with mutual understanding. \\
G 1,2,4,5 & By greeting \\
G 3 & By smiling
\end{tabular}

As to the question of 'What do you think commences communication?', Turkish students have said that such factors as developing empathy, eye contact, posing confidence and listening commence communication; Azerbaijani students have said listening, understanding, personality (they have added that it depends on the person); Turkmen students have said talking, becoming acquainted with somebody greeting and asking questions; Malian students have said greeting, talking, becoming acquainted with somebody and smiling; Somalian students have said greeting, smiling, talking and becoming acquainted with somebody; French students have said smiling, talking (they have added that it depends on the person) and, lastly, Guinean students have said greeting and smiling the factors which commence the communication.

Although the students are culturally different people, it has been revealed that they have similar opinions on the factors which commence the communication. They have agreed that communication initiates with eye contact and smile. During communication, especially face-to-face, whether making eye contact or not may be perceived differently. The students have emphasized this factor. In daily life, as well, communication may be more effective thanks to eye contact. 
Table 4. The Termination of Communication Case

\begin{tabular}{lcl}
\hline Theme & Country & \\
\hline & Turk 1 & By farewells \\
Turk 2 & After shaking hands \\
Turk 3,4 & By saying see you soon \\
Turk 5 & After it was clear to be understood clearly \\
A 1 & After it was clear to be understood clearly \\
A 2 & After it was understood \\
A 3 & By understanding and being understood \\
A 4 & By farewells \\
T 1 & After giving a hug \\
& T 2 & After it was clear to be understood clearly \\
T 3 & By saying see you soon \\
& T 4,5 & After it was clear to be understood clearly \\
M 1 & After shaking hands \\
M 2 & By saying see you soon \\
M 3,4 & After giving a hug \\
M 5 & By farewells \\
4.The way the com- $1,2,5$ & By farewells \\
munication is termi- & By saying see you soon \\
nated & S 4 & After giving a hug \\
& F 1 & After it was clear to be understood clearly \\
& F 2 & By smiling \\
F 3 & In a friendly way \\
F 4 & After shaking hands \\
G 1,2 & By farewells \\
G 3 & After shaking hands and giving a hug \\
G 4 & After giving a hug and saying see you soon \\
G 5 & After shaking hands \\
\hline
\end{tabular}

Related to the way the communication is terminated, Turkish students have said that after it is clearly understood, the communication may be terminated by farewells, then saying see you soon and shaking hands; Azerbaijani students have said it may be terminated after saying see you soon; Turkmen students have said it is terminated after giving a hug and saying see you soon; Malian students have said it is terminated by farewells, giving a hug and shaking hands; Somalian students have said by farewells and after saying see you soon and giving a hug; French students have said it is terminated in a friendly way after smiling and giving a hug; Guinean students have said it is terminated after by farewells, shaking hands and giving a hug.

Some students have stated the importance of being understood clearly whereas other students have emphasized the farewell process while terminating the communication. The fact that the communication is terminated after being understood clearly is of importance. For this reason, in long- term relations, being understood correctly is the key factor in social life as well.

Table 5. Communication Case

\begin{tabular}{lcl}
\hline Theme & Country & \multicolumn{1}{c}{ Opinion } \\
\hline & Turk 1 & Family and friends \\
Turk 2 & Friends \\
Turk 3 & Family and teacher \\
Turk 4 & Friends \\
Turk 5 & Friends \\
& A 1 & Girlfriend or boyfriend \\
& A 2,3,4 & Friends \\
& T 1 & Parents and friends \\
& T 2,3,5 & Friends \\
5. The people who & T 4 & Family and friends \\
M 1,4 & Friends and teacher \\
first in daily life & M 2 & Parents \\
& M 3 & Family and friends \\
M 5 & Family \\
& S 1 & Friends \\
S 2,3,4 & Family and friends \\
S 5 & Family \\
& F 1 & Friends \\
F 2,4 & Family, friends and teacher \\
& F 3 & Friends \\
G 1,2,4 & Friends \\
G3, 5 & Friends and teacher
\end{tabular}


cate with their parents, friends and teachers first in their daily life; Azerbaijani students have said that they communicate with their friends and boyfriends or girlfriends first; Turkmen students have said their family and friends; Malian students have said their family, friends and teachers; Somalian students have said their family and friends; French students have said their family, friends and teachers; Guinean students have said they communicate with their friends and teachers first in their daily life.

Most of the students have stated that they communicate with their friends first in their daily life. With this regard, it has been inferred that communication with friends has the priority. The underlying reason is that the students spend most of their time with their friends as, in this period, friendship relations have more importance than family relationships.

Table 6. Disputes in Communication Case

\begin{tabular}{|c|c|c|}
\hline Theme & Country & Opinion \\
\hline \multirow{21}{*}{$\begin{array}{l}\text { 6. The people com- } \\
\text { municated to dissent } \\
\text { the disputes }\end{array}$} & Turk 1 & Family \\
\hline & Turk 2,3,4,5 & Family and friends \\
\hline & A 1 & Expert \\
\hline & A 2 & Family and friends \\
\hline & A 3 & Friends and teacher \\
\hline & A 4 & Friends \\
\hline & T 1 & Family and friends \\
\hline & T 2 & Friends \\
\hline & T 3,4 & Myself \\
\hline & T 5 & Family \\
\hline & M 1 & Expert and friends \\
\hline & $M 2,5$ & Friends \\
\hline & M 3 & Friends, mother and siblings \\
\hline & M 4 & Expert \\
\hline & S $1,2,3,5$ & Teacher \\
\hline & S 4 & Expert \\
\hline & F 1 & Expert and myself \\
\hline & $F 2,3,4$ & Expert \\
\hline & G $1,2,5$ & Teacher \\
\hline & G 3,5 & Expert \\
\hline & G 4 & Friends \\
\hline
\end{tabular}

As to the question of 'Who do you consult first when you experience a dispute during communication process?', Turkish students have stated that, in case of a dispute, they consult family and friends first; Azerbaijani students have said they consult family, friends, expert and their teachers first; Turkmen students have said themselves, family and teachers to consult first; Malian students have said family, friends and an expert first; Somalian students have said they consult an expert and their teachers first; French students have said themselves and an expert first and Guinean students have said friends, expert and teachers to consult first.

It has been found out that some students prefer friends while others choose their family when they encounter a dispute during communication process. For this reason, it is possible to say that family, as well as friends, is still an option when a dispute emerges in communication.

Table 7. Dissenting the Disputes in Communication Case

\begin{tabular}{|c|c|c|}
\hline Theme & Country & Opinion \\
\hline & Turk 123.5 & Family and friends \\
\hline & Turk 4 & Expert \\
\hline & A 1,2 & Friends \\
\hline & A 3,4 & Expert \\
\hline & T 1 & Family \\
\hline & T 2 & Expert \\
\hline & T $3,4,5$ & Friends \\
\hline & M 1 & Expert \\
\hline 7. The people dis- & M 2,5 & Friends \\
\hline senting the disputes & M 3,4 & Family and expert \\
\hline in your daily life & $\mathrm{S} 1,2$ & Expert \\
\hline & S 3 & Friends \\
\hline & S 4 & Friends and expert \\
\hline & $\begin{array}{ll}\text { S } 5 \\
\text { F } 123\end{array}$ & Expert \\
\hline & $\begin{array}{l}F 1,2,3 \\
F 4\end{array}$ & $\begin{array}{l}\text { Frlends and expert } \\
\text { Friends }\end{array}$ \\
\hline & G 1,2 & Expert \\
\hline & G 3 & Family, friends and expert \\
\hline & G 4,5 & Friends \\
\hline
\end{tabular}

| Kastamonu Eğitim Dergisi, 27(6), 2019| 
As to the question of 'Who do you think dissents the communication dispute more easily in your daily life?', Turkish students have said their family and friends; Azerbaijani students have said their friends and an expert; Turkmen students have said their family, friends and an expert; Malian students have said their family, friends and an expert; Somalian students have said their friends and an expert; French students have said their friends and an expert; Guinean students have said their family, friends and an expert may dissent the disputes easily.

In the current study, some students have expressed that their family and friends may dissent the disputes easily. However, others have stated that an expert may be more beneficial. It has been clearly known that people are now seeking expert advice to dissent the disputes in modern life. Therefore, it has been seen that there are many experts specialized in certain areas and identifying themselves as 'education, sport, and health or life coach.' This indicates, like in many other fields, that specializing in communication emerges. Despite specializing, the fact that family has been considered to dissent the disputes is also worth notice because having confidence in family allows the person to feel safe and express oneself in a better way. As a result, this facilitates a healthy communication among the people.

\section{Table 8. Empathy in Communication Case}

\begin{tabular}{|c|c|c|}
\hline Theme & Country & Opinion \\
\hline $\begin{array}{l}\text { 8.Empathy in Com- } \\
\text { munication }\end{array}$ & $\begin{array}{l}\text { Turk } 1 \\
\text { Turk } 2 \\
\text { Turk } 3 \\
\text { Turk 4,5 } \\
\text { A } 1 \\
\text { A 2,3,4 } \\
\text { T } 1,2 \\
\text { T } 3 \\
\text { T } 4 \\
\text { T } 5 \\
\text { M } 1 \\
\text { M } 2 \\
\text { M } 3 \\
\text { M } 4 \\
\text { M } 5 \\
\text { S } 1 \\
\text { S } 2,3 \\
\text { S } 4 \\
\text { S } 5 \\
\text { F } 1 \\
\text { F } 2 \\
\text { F } 3 \\
\text { F } 4 \\
\text { G } 1 \\
\text { G } 2 \\
\text { G } 3 \\
\text { G } 4 \\
\text { G } 5\end{array}$ & $\begin{array}{l}\text { Smiling to the people } \\
\text { Developing empathy for the other } \\
\text { Commencing the communication } \\
\text { Putting oneself in another's palce } \\
\text { Feeling like the other person } \\
\text { Putting oneself in another's place } \\
\text { Putting oneself in another's place } \\
\text { Behaving in a good manner } \\
\text { Understanding the other person } \\
\text { Understanding the feeling of another } \\
\text { Behaving like the other person } \\
\text { Speaking in a good manner } \\
\text { Feeling for somebody } \\
\text { Behaving like the other person } \\
\text { Talking to somebody } \\
\text { Greeting } \\
\text { Talking } \\
\text { Behaving like the other person } \\
\text { Putting oneself } n \text { another's place } \\
\text { Understanding the other person } \\
\text { Behaving like the other person } \\
\text { Being understood by the other person } \\
\text { Behaving like the other person } \\
\text { Putting oneself in another's place } \\
\text { Putting oneself in another's place } \\
\text { Feeling like the other person } \\
\text { Behaving like the other person } \\
\text { Feeling like the other person }\end{array}$ \\
\hline
\end{tabular}

Based on the theme of showing empathy during communication, Turkish students have said that it includes smiling, developing empathy for the other, putting oneself in another's place and commencing the communication; Azerbaijani students have said feeling like the other person and putting oneself in another's place; Turkmen students have said understanding the feelings of another, putting oneself in another's place, understanding another and behaving in a good manner; Malian students have said behaving like another person, speaking in a good manner, feeling for somebody, behaving like the other person and talking to somebody; Somalian students have said greeting, talking, behaving like the other person and putting oneself in another's place; French students have said understanding the other person, being understood by the other person and behaving like the other person and Guinean students have included putting oneself in another's place, feeling like another person and behaving like the other person.

The students have regarded empathy as putting oneself in another's place. This sense indicates that they confuse and misunderstand empathy and sympathy concepts. Several concepts are being misused in daily life. However, the most essential skill which people should achieve is to develop empathy since it would be inevitable for a society where there are so many disputes due to the people who do not understand one another. 
Table 9. Sympathy in Communication Case

\begin{tabular}{|c|c|c|}
\hline Theme & Country & Opinion \\
\hline \multirow{33}{*}{$\begin{array}{l}\text { 9. Sympathy in Com- } \\
\text { munication }\end{array}$} & Turk 1 & Smiling \\
\hline & Turk 2 & Behaving in a friendly way \\
\hline & Turk 3 & Behaving caresively \\
\hline & Turk 4 & Behaving sympathetically \\
\hline & Turk 5 & Behaving unbiased \\
\hline & A 1 & Behaving in a good-humoured way \\
\hline & A 2 & Being good-humoured \\
\hline & A 3 & Behaving without hurting another \\
\hline & A 4 & Behaving in a good manner \\
\hline & $\mathrm{T} 1$ & Not hurting anybody \\
\hline & $\mathrm{T} 2$ & Behaving in a good manner to people \\
\hline & T 3 & Behaving in a good manner \\
\hline & $\mathrm{T} 4$ & Behaving sympathetically \\
\hline & T 5 & Understanding the people \\
\hline & M 1 & Caring about the other people \\
\hline & M 2 & Behaving sensibly \\
\hline & M 3 & Understanding the people \\
\hline & M 4 & Thinking positively about other people \\
\hline & M 5 & Behaving in a good manner to other people \\
\hline & S 1 & Behaving in a good manner \\
\hline & 52 & Caring about other people \\
\hline & 53 & Understanding the people \\
\hline & S 4 & Thinking positively \\
\hline & S 5 & Being good-humoured \\
\hline & F 1 & Understanding somebody's troubles \\
\hline & F 2 & Caring about the people \\
\hline & F 3 & Behaving positively \\
\hline & F 4 & Caring about the people \\
\hline & G 1 & Being good-humoured \\
\hline & G 2 & Talking in a good-humoured manner \\
\hline & G 3 & Caring about the people \\
\hline & G 4 & Thinking positively \\
\hline & G 5 & Thinking positively about other people \\
\hline
\end{tabular}

As to the question of 'What do you think does sympathy refer in communication?', Turkish students have said that sympathy in communication means smiling and behaving in a friendly, caresively, sympathetically and unbiased; Azerbaijani students have said behaving in a good-humoured way, being smiling, talking without hurting another and behaving in a good manner; Turkmen students have said not hurting anybody, behaving in a good manner, behaving sympathetically and understanding the people; Malian students have said caring about the people, behaving sensibly, understanding and behaving the people in a good manner and thinking positively about them; Somalian students have said behaving in a good manner, caring about the people, understanding them and being smiling; French students have said understanding somebody's troubles, behaving positively and caring about the people and, lastly, Guinean students have said it means being good-humoured, talking in a good manner, caring about the people, thinking positively about them.

A sympathetic behaviour is to feel for somebody because of the things that have happened to them. The statement 'behaving sympathetically' is used by the students apart from its academic definition. As a result, the word 'sympathetic' is misused as kindness or loveliness in daily language. However, the fact that the students have emphasized the concepts of caring about the people and being unbiased against them is worth notice. 
Table 10. The State of the Speaker in communication Case

\begin{tabular}{|c|c|c|}
\hline Theme & Country & Opinion \\
\hline \multirow{32}{*}{$\begin{array}{l}\text { 10. The Speaker during } \\
\text { Communication }\end{array}$} & Turk 1 & 1.tone of voice, 2.eyes, 3.eye contact, 4.posture \\
\hline & Turk 2 & 1.tone of voice, 2.clothes, 3.face \\
\hline & Turk 3 & 1.tone of voice, 2.face, 3.posture \\
\hline & Turk 4 & 1.height, 2.clothes, 3.tone of voice \\
\hline & Turk 5 & 1.tone of voice, 2.posture, 3.eye contact \\
\hline & A 1 & 1.tone of voice, 2 . posture, 3.eye contact \\
\hline & A 2 & 1.posture, 2.eyes \\
\hline & A 3 & 1.tone of voice, 2 . posture, 3.eye contact \\
\hline & A 4 & 1.posture, 2.eye contact, 3.tone of voice \\
\hline & T 1 & 1.posture, 2.tone of voice, 3.eye contact \\
\hline & Т 2 & 1.clothes, 2.tone of voice, 3.eye contact \\
\hline & T 3 & 1.clothes, 2.face, 3.tone of voice \\
\hline & T 4 & 1.tone of voice, 2.clothes \\
\hline & T 5 & 1.tone of voice, 2.posture, 3.eye contact \\
\hline & M 1 & 1.tone of voice, 2.clothes \\
\hline & M 2 & 1.tone of voice, 2.face, 3.eye contact \\
\hline & M 3 & 1.tone of voice, 2.clothes \\
\hline & M 4 & 1.sex, 2.tone of voice, 3.face \\
\hline & M 5 & 1.eyes, 2.tone of voice \\
\hline & S 1,2 & 1.sex, 2.tone of voice \\
\hline & S 3 & 1.sex, 2.face \\
\hline & S 4 & 1.face, 2.clothes \\
\hline & S 5 & 1.eyes, 2. face \\
\hline & F 1 & $\begin{array}{l}\text { 1.bright-coloured clothes, 2.unusual clothes, 3.soft voice, 4.appealing } \\
\text { speech, 5.body language }\end{array}$ \\
\hline & F 2 & 1.clothes, 2.height, 3.sex \\
\hline & F 3 & 1.body language, 2 . content of the message \\
\hline & F 4 & 1.sex, 2.weight, 3.beauty, 4.clothes \\
\hline & G 1 & 1.eye contact, 2.posture, 3.face \\
\hline & G 2 & 1.eye contact, 2.sex, 3.height \\
\hline & G 3 & 1.tone of voice, 2 .eyes \\
\hline & G 4 & 1.eyes, 2.clothes, 3.face \\
\hline & G 5 & 1.tone of voice, 2.clothes, 3.height \\
\hline
\end{tabular}

Based on the theme of speaker's prominent feature during communication, Turkish students have said tone of voice; Azerbaijani students have said tone of voice and posture; Turkmen students have said tone of voice, clothes and posture; Malian students have said tone of voice, sex and eyes; Somalian students have said sex, face and eyes; French students have said clothes, body language and sex; lastly, Guinean students have said eye contact, tone of voice and eyes.

The fact that students focus on speaker's body language is worth notice. On the contrary, students have not mentioned about the content or style of the speech. For this reason, it may be concluded that the words uttered during communication do not directly mean a lot for them.

\section{Discussion and Results}

Communication is a way that enables sense of belonging, corporation and association (Tomasello, 2008; Gluzek et al., 2010; Kim and Kang, 2010; Kruse, 2016). However, it varies from culture to culture. Among the reasons that communication shows difference are the experience and life-style (Elving, 2005; Giles and Togay, 2007; Wrench et al., 2009). In the current study, it was aimed to reveal the views of the students from different countries via asking the same questions: they have given similar answers to the first question of the study which is 'What is effective communication?' and it has been found out that students' answers and the definition of the word coincides with one another. In addition, they agree that being understood correctly is also essential in communication.

According to the previous studies, effective communication is most influenced by the meaning of the message (Özgan and Aslan, 2008; Wood, 2010; Elgünler and Fener, 2011). However, students have stated the other factors instead of the meaning in the second question of the study which is 'What affects an effective communication?'. The results indicate that physical features of the speaker have been attached more importance than the message. In addition, termination of an effective communication is as important as commencement of it. One of the most crucial points which commence the communication is that the one commencing it should have comprehensive knowledge (Fallowfield and Jenkins, 1999; Dunbar, Bippus and Young, 2008).

In the third question of the study which is 'What do you think commences communication?', the students have emphasized physical features. As a result, the points stated by them and findings of the studies do not compromise with 
one another. This reveals that body language and tone of voice is as important as the message. Therefore, the fact that speaker is able to impress the audience properly depends on terminating the communication in a correct and effective way (MohrandSohi, 1995).

As to the fourth question of the study- How should an effective communication be terminated?- the students have given similar answers although they have different countries and cultures. Therefore, it has been inferred that termination of communication gains universal approach. The people have different style of speech although their socializing behaviours show similarities (Coleman, 1988; DavidssonandHonig, 2003; Salmon ve Perkins, 2009). They communicate with different people as they get older. Depending on this, feelings, views and information shared during communication varies.

To the fifth question of the study which is 'Who do you communicate first in your daily life? (Write in order of importance)', almost all students have emphasized their family and friends, indicating that family and friends are still important to them. On the contrary, there may be several disputes among people in different time and places and they experience those disputes to some extent depending on their state and status (Tavakolizadeha, Nejatianband Soori, 2015).

In the sixth question of the study which is 'Who do you consult first when you experience a dispute during communication process? (Write in order of importance)', students have chosen their family and friends as mentioned above. The fact that their first preference is family reveals that family is still safe institution for them. However, French and Guinean students have stated expert and friends. This may be associated with their cultural life-styles as, in Western societies, family relations show difference after certain periods. Correspondingly, students communicate with different people except from family.

Communication between people may be affected by their daily life and they may encounter certain disputes. They consult different people to dissent those disputes (Kayes, 2006). To the seventh question of the study which is 'Who do you think dissents the communication dispute more easily in your daily life?', Turkish students have said their family and friends; Azerbaijani students have said their friends and an expert; Turkmen students have said their family, friends and an expert; Malian students have said their family, friends and an expert; Somalian students have said their friends and an expert; French students have said their friends and an expert; Guinean students have said their family, friends and an expert may dissent the disputes easily. It has been revealed that students choose their families first, and secondly, their friends. The fact that they regard their families as an effective option for dissenting the disputes is of importance. However, the reason why French and Guinean students prefer an expert or their friends to dissent the disputes may be related to their culture.

The act of understanding the other people is relatively important. Feeling for somebody, and then, communicating with them is an expected behavior for people since empathy in communication is quite essential. Empathy is, as its simplest, awareness of the feelings and emotions of other people and having the ability to propose a solution (Roberts and Strayer, 1996; Dökmen, 2005). To the eighth question of the study which is 'What do you think is showing empathy during communication?', students have been found to misuse the concepts of empathy and sympathy. However, an empathetic behavior is expected to suggest a solution. On the contrary, students have not mentioned about solutions during the interviews as empathy is mostly confused with sympathy. Sympathy is the feelings and opinions' being expressed clearly and, then, feeling for somebody else because of something that has happened to them (Weiner, 1995). In this regard, it is very important for a person to feel for somebody else. Therefore, the people who have sympathetic behavior tend to feature their emotional reactions rather than to find a solution for one another. However, this situation makes the matters worse.

In the ninth question of the study which is 'What do you think does sympathy refer in communication?', students have defined sympathetic behaviour as feeling for somebody else, as its meaning in daily language. It has also been revealed that they consider sympathetic behaviour the same as caring about the people.

During an effective communication, such elements as tone of voice, clothes and their colors' and body language make difference (Burener, 1984; Barkai, 1990; Meeren et al., 2005; Gelder, 2007; Levine, Theobalt and Koltun, 2009; Dumbravă and Koronka, 2009). To the last question of the study which is 'What do you think are the speaker's prominent features during communication? (Write in order of importance)', Turkish students have said tone of voice; Azerbaijani students have said tone of voice and posture; Turkmen students have said tone of voice, clothes and posture; Malian students have said tone of voice, sex and eyes; Somalian students have said sex, face and eyes; French students have said clothes, body language and sex; lastly, Guinean students have said eye contact, tone of voice and eyes.

Tone of voice is an important feature for the other ones except from Turkish students. In daily life, voice is considered to be important in that it both facilitates communication and has an impression on people. In addition, another factor which affects communication is style of dressing since clothes are regarded as important elements in most cultures. Style

| Kastamonu Eğitim Dergisi, 27(6), 2019| 
of dressing, as is known, has become a sign of the status and social prestige for people in many fields of business. In social life, people's style of hair and dressing represents their communicating skills. In conclusion, communication and dissenting the disputes require a skill. It is essential to gain this skill in the family, improve and maintain it in formal environments.

\section{References}

Ainsworth, M. (1979). Infant-mother attachment. American Psychologist, 34(10), 932-937.

Aksüt, M., Batur, Z. \& Avşar, T. (2006). Sanalca, sanal odalarda (internet) iletişim ve Türkçe, Akademik Bilişim'06 - VIII. Akademik Bilişim Konferansı Bildirileri.

Aksüt, M.\& Batur, Z. (2007). Internet perspektifinde ergenlerin sosyalleşme ve iletişim kurma süreci, Akademik Bilişim’07 - IX. Akademik Bilişim Konferansı Bildirileri. 31 Ocak 2 Şubat 2007 Dumlupunar Üniversitesi Kütahya

Ames, D., Maissen, L. B. \& Brockner, J. (2012). The role of listening in interpersonal influence. Journal of Research in Personality 46(3), 345349.

Barkai, J. L. (1990). Nonverbal communication from th eother side: Speaking body language. San Diego Law Review, 27(101), 102-125.

Başar, M, Doğan, C., Şener, N., Uzun, Ö.,\&Topal H. (2018) Illkokulda öğretmen öğrenci iletişimi Uşak Üniversitesi Eğitim Araştırmaları Dergisi 4(1) 1-17

Batur, Z. (2010). Kitle iletişim araçlarının oluşturduğu yeni bir dil katmanı: öğretmen adaylarının kullandığı kitle iletişim jargonu, Uşak Üniversitesi Sosyal Bilimler Dergisi, 3(2), 63-73.

Batur, Z. \& Uygun, K. (2012). i̇ki neslin bir kavram algısı:Teknoloji. Uşak Üniversitesi Sosyal Bilimler Dergisi, 5(1), 74-88.

Bozorgian, H. (2012). Metacognitive instruction does improve listening comprehension. International Scholarly Research Network, 1-6.

Brownell, J. (1994). Creating strong listening environments: A key hospitality management task. International Journal of Contemporary Hospital Management, 6(3) 3-10.

Burener, J. (1984) Interaction, communication, and self. Journal of the American Academy of Child Psychiatry, 23(1), 1-7.

Castleberry, S. \& Shepherd, D. (1993). Effective interpersonal listening and personal selling. Journal of Personal Selling \& Sales Management, 13(1), 35-49.

Cochran, M. \& Brassard, J. (1979). Child development and personal social networks. Child Development, 50(3), 601-616.

Coleman, J. S. (1988). Social capital in the creation of human capital. The American Journal of Sociology, 94, 95-120.

Davidsson, P. \& Honig, B. (2003). The role of social and human capital among nascent entrepreneurs. Journal of Business Venturing 18(3), 301-331.

Deniz, K. (2013). Eğitimde etkili iletişim, Ed. H. Karatay, Türkçe öğretimi el kitabı. Ankara:Pegem Akademi.

Dumbrav, G. \& Koronka, A. (2009). Actions speak louder than words" - body language in business communication. Annals of the University of Petroşani, Economics, 9(3), 249-254.

Dunbar, N. E., Bippus, A. M. \& Young, S. L. (2008). Interpersonal dominance in relational conflict: a view from dyadic power theory. Interpersona, 2(1), 1-33.

Elgünler, T. Ç. \& Fener, T. (2011). iletişimin kalitesini etkileyen engeller ve bu engellerin giderilmesi. The Turkish Online Journal of Design, Art and Communication - TOJDAC, 1(1), 35-39.

Elving, W. J. L. (2005). The role of communication in organisational change. Corporate Communications: An International Journal, 10(2), 129-138.

Goh, C. C. (2000). A cognitive perspective on language learners' listening comprehension problems. System, 28(1), 55-75.

Gelder, B. (2007). Towards the neurobiology of emotional body language. Nature Reviews Neuroscience, 7, $242-249$.

Giles, H. \& Ogay, T. (2007). Communication Accommodation Theory, In B. B. Whaley and W. Samter (Eds.), Explaining communication: Contemporary theories and exemplars (293-310). Mahwah, NJ: Lawrence Erbaum.

Gluzek, A. \& Dovidio, J. F. (2010). Speaking with a nonnative accent: Perceptions of bias, communication difficulties, and belonging in the United States. Journal of Language and Social Psychology, 29(2), 224-234.

Graham, S. (2006). Listening comprehension: The learners' perspective. System, 34, 165-182.

Halawah, I. (2005). The relationship between effective communication of high school principal and school climate. Education, $126(2), 334-345$.

Hamouda, A. (2013). An investigation of listening comprehension problems encountered by Saudi students in the EL listening classroom. International Journal of Academic Research in Progressive Education and Development, 2(2), 113-155.

Harvey, M. \& Griffith, D. (2002). Developing effective intercultural relationships: the importance of communication strategies. Thunderbird International Business Review, 44(4) 455-476.

Hoff, E. (2003). The specificity of environmental Influence: socioeconomic status affects early vocabulary development via maternal speech. Child Development, 74(5), 1368-1378.

Fallowfield, L. \& Jenkins, V. (1999). Effective communication skills are the key to good cancer care, European Journal of Canser, 35(11), 1592-1597.

Janusik, L. A. \& Wolvin, A. D. (2002). Listening treatment in the basic communication course text. Basic Communication Course Annual, 14(11), 164-210

Kraut, R., Fish, R. S., Root, R. W. \& Chalfonte, B. L. (1990). Informal communication in organizations: form, function, and technology, I S. Oskamp\& S. Spacapan (Eds.). Human Reactions to Technology: The Claremont Symposium on Applies Social Psychology. Beverly Hills, 
CA: Sage Publications.

Kim, Y. \& Kang, J. (2010). Communication, neighbourhood belonging and household hurricane preparedness. Disasters, 34(2), $470-488$.

Kayes, P. E. (2006). New paradigms for diversifying faculty and staff in higher education: uncovering cultural biases in the search and hiring process. Multicultural Education, 65-69.

Kruse, N. (2016). Feelings of belonging in a congregation: a social- psychological assessment. Mental Health, Religion \& Culture, 19(2), 164177.

Lau, K. L. (2017) Strategy use, listening problems, and motivation of high and low-proficiency Chinese listeners. The Journal of Educational Research, 110(5), 503-514.

Lotfi, L. (2012). A questionnaire of beliefs on english language listening comprehension problems: development and validation. World Applied Sciences Journal, 16(4), 508-515.

Leonard, M., Graham, S. \& Bonacum, D. (2004). The human factor: the critical importance of effective teamwork and communication in providing safe care. QualSaf Health Care, 13(1), 85-90.

Levine, S., Theobalt, C. \& Koltun, V. (2009). Real-time prosody-driven synthesis of body language. ACM Transactions on Graphics, 2-9.

Liyanage, C., Ballal, T., Elhag, T. \& Li, Q. (2009). Knowledge communication and translation A knowledge transfer model. Journal of Knowledge Management, 13(3), 118-131.

Meeren, H. K., Van Heijnsbergen, C. C., \& De Gelder, B. (2005). Rapid perceptual integration of facial expression and emotional body language. Proceedings of the National Academy of Sciences of the United States of America, 102(45), 16518-16523.

Miles, M. B. \& Huberman, A. M. (1994). Qualitive data analysis. California: Sage Pub

Mohr, J. J. \& Sohi, R. S. (1995). Communication Flows in Distribution Channels: Impact on Assessments of Communication Quality and Satisfaction. Journal of Retailing, 71(4), 393-416.

Moore, D. R., Halliday, L. F., \& Amitay, S. (2009). Use of auditory learning to manage listening problems in children. Philosophical transactions of the Royal Society of London. Series B, Biological sciences, 364(1515), 409-420.

Özgan, H. \& Aslan, N. (2008). illköğretim okul müdürlerinin sözlü iletişim biçiminin öğretmenlerin motivasyonuna etkisinin incelenmesi. Gaziantep Üniversitesi Sosyal Bilimler Dergisi, 7(1), 190-206.

Pierce, T. (2009). Social anxiety and technology: Face-to-face communication versus technological communication among teens. Computers in Human Behavior, 25, 1367-1372.

Rains, A. \& Scott, R. (2007). To Identify or Not to Identify: A Theoretical Model of Receiver Responses to Anonymous Communication. Communication Theory, 17, 61-91.

Renn O., Levine D. (1991) Credibility and trust in risk communication. In: Kasperson R.E., Stallen P.J.M. (eds) Communicating Risks to the Public. Technology, Risk, and Society (An International Series in Risk Analysis), vol 4. Springer, Dordrecht

Roberts, W. \& Strayer, J. (1996). Empathy, emotional expressiveness, and prosocial behavior. Child Development, 67(2), $449-470$.

Ryan, E. B., Meredith, S. D., Maclean, M. J. \& Orange, J. B. (1995). Changing the way we talk with elders: promoting health using the communication enhancement model. International Journal of Aging and Human Development, 41(2), 69-107.

Salmon, G. \& Perkins, D. (2009). Individual and social aspects of learning. Review Of Research In Education, 23(1), 1-24.

Selwyn, N. (2003). Apart from technology: understanding people's non-use of information and communication technologies in everyday life. Technology in Society 25, 99-116.

Socha, T. \& Pitts, M. (2009). The positive side of interpersonal communication. New York: Peter Lang.

Suter, E., Arndt, J., Arthur, N., Parboosingh, J., Taylor, E. \& Deutschlander, S. (2009). Role understanding and effective communication as core competencies for collaborative practice. Journal of Interprofessional Care, 23(1), 41-51.

Stewart, K. (1978). And daddy makes three: the father's Impact on mother and young child. Child Development, 49(2), $466-478$.

Street, R., Brady, R. \& Putman, W. (1983). The influence of speech rate stereotypes and rate similarity or listeners' evaluations of speakers. Journal of Language and Social Psycology, 2(1), 37-56.

Sypher, B. D., Bostrom, R. \& Seibert, J. (1989). Listening, communication abilities, and success at work. The Journal of Business Communication, 26(4), 293-303.

Tavakolizadeha, J., Nejatianb, M. \& Soori, A. (2015). The Effectiveness of communication skills training on marital conflicts and its different aspects in women. Procedia - Social and Behavioral Sciences, 171, 214 - 221.

Tomasello, M. (2008). Origins of human communication. Cambridge, Mass : A Bradford Book.

Vandergrift, L. (1997). The Cinderella of communication strategies: reception strategies in interactive listening. The Modern Language Journal, 81(4), 494-505.

Weigner, B. (1995). Judgments of Responsibility: A Foundation for a theory of social conduct. The Guilford Press: New York London.

Wolvin, A. (2010). Listening and human communication in the 21st century. UK: Blackwell Publishing Ltd.

Wood, J. T. (2010). Interpersonal communication: everyday encounters. Sixth Edition, Publisher: Lyn Uhl.

Wrench, J. S., Corrigan M. W., McCroskey J. C. \& Panyanunt-Carter, N. M. (2006). Religious fundamentalism and Intercultural communication: the relationships among ethnocentrism, intercultural communication apprehension, religious fundamentalism, homonegativity, and tolerance for religious disagreements. Journal of Intercultural Communication Research, 35(1), 23-44.

Yıldırım, A. \& Şimşek, H. (2011). Sosyal bilimlerde nitel araştırma yöntemleri. Ankara: Seçkin 